\title{
PENGARUH HIDROKOLOID PADA MUTU PRODUK BAKERI
}

\author{
M. Khoiron Ferdiansyah ${ }^{1)^{\star}}$ \\ 1) Program Studi Teknologi Pangan, Fakultas Teknik dan Informatika, \\ Universitas PGRI Semarang, J1. Sidodadi Timur 24 Semarang \\ $\left.{ }^{*}\right)$ Email: khoironferdiansyah@upgris.ac.id
}

\begin{abstract}
ABSTRAK
Beberapa penelitian telah dilakukan terkait dengan potensi penggunaan hidrokoloid dalam industri bakeri. Peningkatan kualitas produk bakeri dapat diperoleh dengan penambahan hidrokoloid. Penambahan hidrokoloid ke dalam adonan dapat meningkatkan stabilitas dan kriteria kualitas seperti peningkatan penyerapan air, volume roti dan sifat viskoelastik. Dari beberapa penelitian dapat disimpulkan bahwa semua hidrokoloid yang digunakan dalam perlakuan penelitian berpengaruh terhadap stabilitas adonan dan terbukti dapat meningkatkan kapasitas penyerapan air yang lebih tinggi. Hidrokoloid juga berpengaruh pada sifat sensori produk akhir.
\end{abstract}

Kata kunci: hidrokoloid, bakeri, kualitas

The Effect of Hydrocolloids on Quality of Bakery Product

\begin{abstract}
Several studies have been carried out showing the potential use of hydrocolloids in the bakery industry. An improvement in bakery product quality can be obtained by the addition of hydrocolloids. the addition of hydrocolloids to dough improves its stability and quality criteria such as increased water absorption, specific loaf volume and the viscoelastic properties. From several studies concluded that all from examined hydrocolloids positively affected dough stability and proved higher water absorption capacity. These compounds also affected sensory properties of final products.
\end{abstract}

Keywords: hydrocolloid, bakery, quality

\section{PENDAHULUAN}

Saat ini, penggunaan bahan tambahan pangan telah menjadi praktik umum di industri bakeri. Tujuan penggunaannya adalah untuk meningkatkan karateristik dan penanganan adonan, meningkatkan kualitas dan memperpanjang umur simpan produk bakeri (Rosell dkk., 2001). Hidrokoloid adalah bahan multifungsi yang menambah fleksibilitas, berfungsi sebagai pengganti lemak, pengikat air, texturizers dan perekat (Gurkin, 2002). Hidrokoloid juga telah digunakan dalam pengurangan serapan minyak dalam produk sereal (Albert dan Mittal, 2002). Jenis hidrokoloid yang paling dikenal dan diterapkan dalam industri pangan antara lain yaitu alginat, karagenan, agar, guar gum, getah arab, MC dan CMC (Gomez-Diaz dan Navaza, 2003).

Beberapa penelitian telah dilakukan terkait dengan penggunaan hidrokoloid dalam industri bakeri. Peningkatan stabilitas adonan dapat diperoleh dengan penambahan hidrokoloid, yaitu natrium alginat, karagenan, gum xanthan dan HPMC (Rosell dkk., 2001). Schiraldi dkk., (1996) melaporkan penggunaan guar gum dan locus bean dapat meningkatkan kualitas produk bakeri, meskipun tidak menemukan peran antistaling yang jelas. Penelitian ini dilakukan untuk 
mengetahui pengaruh penambahan hidrokoloid pada kualitas produk bakeri.

\section{PENGARUH HIDROKOLOID TERHADAP SIFAT REOLOGI PRODUK BAKERI}

Karakteristik reologi mencerminkan sifat adonan selama pemrosesan dan kualitas produk akhir (Shahzadi dkk, 2005). Rao dkk. (1992) melaporkan peningkatan penyerapan air oleh tepung terigu dengan penambahan berbagai hidrokoloid. Penyerapan air meningkat dengan penambahan hidrokoloid yang diaplikasikan dan berkisar antara 60,5 hingga $68,3 \%$. Hasil ini diharapkan karena gugus hidroksil dalam struktur hidrokoloid, yang memungkinkan lebih banyak interaksi air melalui pengikatan hidrogen. Waktu pengembangan adonan menurun pada semua hidrokoloid kecuali gum xanthan. Stabilitas adonan adalah indikator kekuatan tepung, dengan nilai yang lebih tinggi menunjukkan adonan yang lebih kuat (Rosell dkk., 2001). Stabilitas adonan yang diteliti dipengaruhi secara positif oleh hidrokoloid, sementara mixing tolerance index tidak dipengaruhi oleh adanya penambahan hidrokoloid. Elastisitas adonan berkurang dengan penambahan hidrokoloid kecuali guar gum.

Tabel 1. Pengaruh penambahan hidrokoloid terhadap sifat farinograph produk bakeri

\begin{tabular}{lccccc}
\hline \multicolumn{1}{c}{ Sample- Próbka } & S & A & G & X & M \\
\hline $\begin{array}{l}\text { Water absorption, \% } \\
\text { Absorpcia wody, \% }\end{array}$ & $59 \pm 0.50$ & $60.5 \pm 0.40$ & $63.3 \pm 0.80$ & $68.3 \pm 1.00$ & $68.2 \pm 0.80$ \\
$\begin{array}{l}\text { Dough development time, min } \\
\text { Czas rośnięcia ciasta, min }\end{array}$ & $6 \pm 0.20$ & $2.5 \pm 0.05^{*}$ & $4 \pm 0.10$ & $7 \pm 0.10$ & $1.75 \pm 0.04^{*}$ \\
$\begin{array}{l}\text { Degree of softening, BJ } \\
\text { Stopień zmiękczenia, BJ }\end{array}$ & $80 \pm 2.00$ & $80 \pm 1.50$ & $40 \pm 0.70^{*}$ & $50 \pm 0.50$ & $20 \pm 0.30^{*}$ \\
$\begin{array}{l}\text { Dough stability, min } \\
\text { Stabilność ciasta, min }\end{array}$ & $5.5 \pm 0.20$ & $6.5 \pm 0.30$ & $13.5 \pm 0.50^{*}$ & $9 \pm 0.30^{*}$ & $14 \pm 0.40^{*}$ \\
$\begin{array}{l}\text { Mixing tolerance index BJ } \\
\text { Wskaźnik tolerancji mieszania, BJ }\end{array}$ & $50 \pm 0.40$ & $50 \pm 0.80$ & $50 \pm 0.80$ & $30 \pm 0.70^{*}$ & $50 \pm 0.50$ \\
$\begin{array}{l}\text { Elasticity, BJ } \\
\text { Elastyczność, BJ }\end{array}$ & $70 \pm 1.00$ & $60 \pm 0.80^{*}$ & $70 \pm 1.50$ & $60 \pm 1.00^{*}$ & $60 \pm 0.70^{*}$ \\
\hline
\end{tabular}

*Means are significantly different from control sample at $\alpha=0.05$.

*Wartości są statystycznie istotne dla próby kontrolnej na poziomie $\alpha=0,05$.

Sumber: Kohajdova dan Karovicova (2008)

Keterangan:

S: kontrol (tanpa penambahan hidrokoloid)

A: penambahan hidrokolid gum arabic

G: penambahan hidrokoloid guar gum

$X:$ penambahan hidrokoloid xanthan gum

M: penambahan hidrokoloid methyl 2-hydroxyethyl cellulose 


\section{PENGARUH HIDROKOLOID TERHADAP SIFAT TEKSTUR PRODUK BAKERI}

Pengencangan remah roti selama penyimpanan adalah fenomena umum dan mengarah ke tekstur yang rapuh, dan penerimaan konsumen yang lebih rendah $(\mathrm{Ji}$ dkk., 2007). Parameter ini adalah parameter yang digunakan untuk mengevaluasi perkembangan staling (Ribotta dan Le Bail, 2007). Semua dari hidrokoloid yang diaplikasikan kecuali metil 2-hidroksietil selulosa dapat mengurangi kekencangan, memberikan remah yang lebih lunak dibandingkan dengan sampel standar atau yang disimpan. Meskipun ditemukan bahwa derivat selulosa mampu menghambat migrasi kelembaban ke permukaan roti dan dengan demikian menghambat proses staling selama penyimpanan (Bárcenas dan Rosell, 2006). Penambahan metil 2-hydroxyethyl selulosa dapat meningkatkan kekencangan remahremah roti sebagai efek penebalan pada dinding remah di sekitar ruang udara. Roti dengan guar gum ditampilkan lebih lembut dibandingkan dengan produk yang mengandung gum arab dan gum xanthan tidak hanya pada produk standar tetapi juga selama 72 jam penyimpanan. Efek pelunakan dari hidrokoloid ini dapat disebabkan oleh penghambatan retrogradasi amilopektin, karena guar gum secara istimewa berikatan dengan pati. Hal ini dikarenakan penambahan gum guar dapat mempengaruhi jaringan amilosa yang menghambat pembentukan matriks spons (Shalini dan Laxmi, 2007).

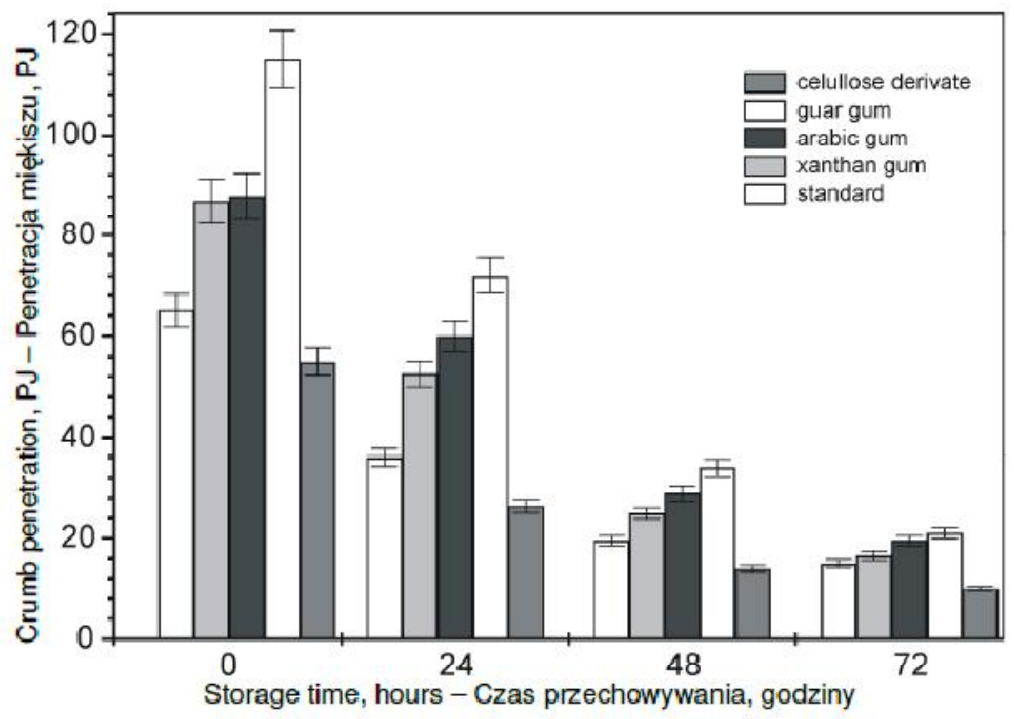

Gambar 1. Pengaruh penambahan hidrokoloid pada crumb penetration (Kohajdova dan Karovicova, 2008)

\section{PENGARUH HIDROKOLOID TERHADAP LOAF VOLUME DAN CAMBERING PRODUK BAKERI}

Volume roti dianggap sebagai karakteristik roti paling penting karena memberikan pengukuran kuantitatif hasil pemanggangan. Pengaruh hidrokoloid yang diterapkan pada volume produk disajikan pada Tabel 2. Hanya penambahan gum arab dan guar gum yang secara positif mempengaruhi parameter ini. Peningkatan volume roti sekitar $19,7 \%$ dan $20,8 \%$ masingmasing dibandingkan dengan sampel kontrol. Schober dkk. (2002) menyatakan bahwa bentuk dan cambering roti merupakan parameter kualitatif yang penting karena spelt bread cenderung menjadi datar. Melarutkan wheatspelt sangat dipengaruhi oleh guargum. 
Penambahan gum xanthan tidak berpengaruh pada cambering produk akhir.

Tabel 2. Pengaruh penambahan hidrokoloid terhadap loaf volume dan cambering produk bakeri

\begin{tabular}{ccl}
\hline $\begin{array}{c}\text { Sample } \\
\text { Próba }\end{array}$ & $\begin{array}{c}\text { Loaf volume } \\
\text { Objętość pieczywa } \\
\mathrm{cm}^{3}\end{array}$ & $\begin{array}{c}\text { Cambering } \\
\text { Wypukłość }\end{array}$ \\
\hline Control & $269 \pm 5.00$ & $0.50 \pm 0.02$ \\
A & $322 \pm 5.50^{*}$ & $0.48 \pm 0.02^{*}$ \\
G & $325 \pm 4.50^{*}$ & $0.60 \pm 0.01^{*}$ \\
X & $223 \pm 4.00$ & $0.50 \pm 0.03$ \\
M & $210 \pm 3.50$ & $0.42 \pm 0.01^{*}$ \\
\hline
\end{tabular}

*Means are significantly different from control sample at $\alpha=0.05$.

*Wartości są statystycznie istotne dla próby kontrolnej na poziomie $\alpha=0,05$.

Sumber: Kohajdova dan Karovicova (2008)

Keterangan:

A: penambahan hidrokolid gum arabic

G: penambahan hidrokoloid guar gum

$X$ : penambahan hidrokoloid xanthan gum

M: penambahan hidrokoloid methyl 2-hydroxyethyl cellulose

\section{PENGARUH HIDROKOLOID TERHADAP SIFAT SENSORIS PRODUK BAKERI}

Dari evaluasi sensorik dihasilkan bahwa produk roti yang mengandung gum arabic dan gum xanthan mempunyai lebih sedikit porositas dan roti dengan gum xanthan, serta turunan selulosa menunjukkan elastisitas remah rendah dibandingkan dengan sampel kontrol. Produk bakeri dengan turunan selulosa juga disajikan sebagai produk dengan struktur yang kompak. Roti dengan gum arab memiliki warna kerak yang lebih gelap seperti roti lainnya. Penambahan hidrokoloid tidak mempengaruhi bau dan rasa produk akhir. Analisis sensori menunjukkan bahwa penambahan guar gum meningkatkan sifat sensoris dari produk bakeri, serta memberikan tingkat sensorik yang lebih tinggi daripada sampel kontrol. 


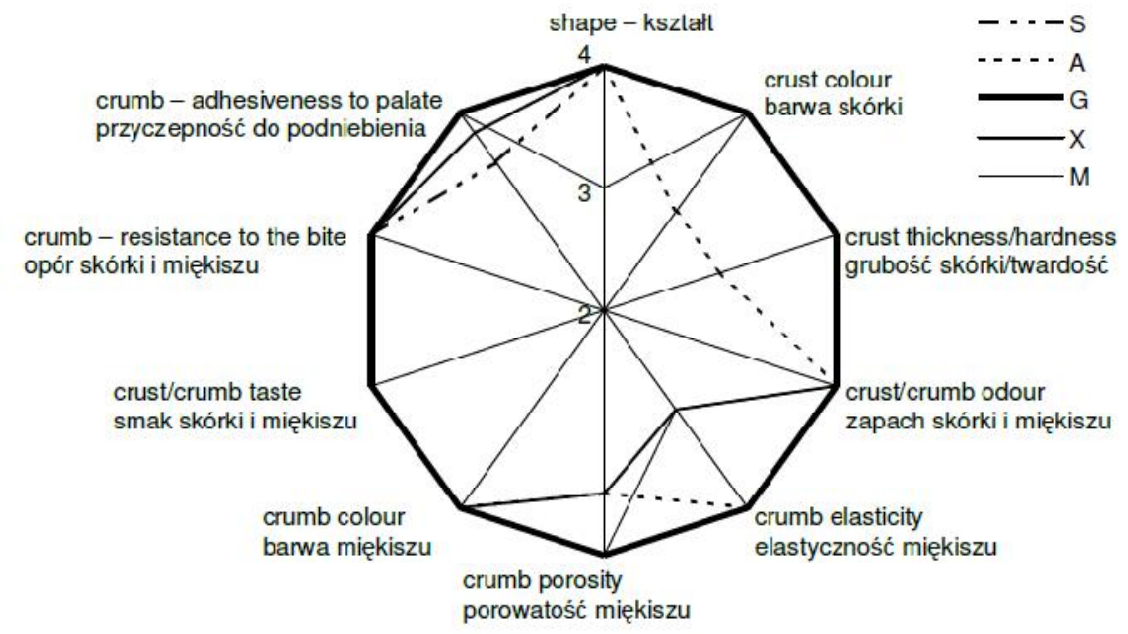

Gambar 2. Pengaruh penambahan hidrokoloid terhadap sifat sensoris produk bakeri (Kohajdova dan Karovicova, 2008)

Keterangan:

S: kontrol (tanpa penambahan hidrokoloid)

A: penambahan hidrokolid gum arabic

G: penambahan hidrokoloid guar gum

$\mathrm{X}$ : penambahan hidrokoloid xanthan gum

M: penambahan hidrokoloid methyl 2-hydroxyethyl cellulose

\section{PENGARUH HIDROKOLOID TERHADAP SIFAT HIDRASI PRODUK BAKERI}

Sifat interaksi protein-polisakarida dapat bervariasi bergantung pada struktur biopolimer dan kondisi pelarut. Kondisi tersebut juga bergantung pada interaksi makromolekul spesifik atau nonspesifik, serta lemah atau kuat. Le'on dkk. (2000) menemukan bahwa gugus amino hidrofobik glutamin yang ada dalam protein gluten berinteraksi dengan kelompok sulfat karagenan. Efek hidrokoloid pada sifat fungsional adonan dan kualitas roti tergantung pada sifat, asal, dan ukuran partikel hidrokoloid dan dosis hidrokoloid yang dimasukkan ke dalam formulasi adonan.

Tabel 3. Karakteristik hidrasi dari hydrated vital gluten dengan adanya penambahan hidrokoloid

\begin{tabular}{lcccc}
\hline Sample & $\begin{array}{c}\text { Hydrocolloid level } \\
\text { (g/g gluten) }\end{array}$ & $\begin{array}{c}\text { Swelling } \\
(\mathrm{mL} / \mathrm{g})\end{array}$ & $\begin{array}{c}\text { Water holding capacity } \\
\text { (g water/g solid) }\end{array}$ & $\begin{array}{c}\text { Water binding capacity } \\
\text { (g water/g solid) }\end{array}$ \\
\hline Control & 0.000 & 4.16 & 3.34 & 1.53 \\
& 0.002 & 4.24 & 3.24 & 1.52 \\
HPMC & 0.007 & 3.88 & 2.99 & 1.44 \\
& 0.013 & 3.63 & 2.98 & 1.47 \\
Arabic gum & 0.002 & 4.15 & 3.35 & 1.56 \\
& 0.007 & 4.10 & 3.26 & 1.58 \\
Pectin & 0.013 & 4.20 & 3.28 & 1.49 \\
& 0.002 & 3.96 & 2.99 & 1.63 \\
& 0.007 & 3.78 & 2.96 & 1.64 \\
\hline
\end{tabular}

Sumber: Pahwa , 2016 
Pengaruh tiga hidrokoloid (gum arab, pektin, dan HPMC) pada karakteristik gluten telah diteliti (Barcenas dkk., 2009). Karakteristik gluten adalah sifat hidrasi (pembengkakan, kapasitas retensi air, dan kapasitas pengikatan air), kualitas gluten (indeks gluten, jumlah gluten basah dan kering), ekstraksi protein natrium dodesil sulfat, dan sifat reologi (modulus elastis dan viskositas). Hasil penelitian menunjukkan bahwa sifat gluten dipengaruhi oleh hidrokoloid pada tingkat yang berbeda tergantung pada jenis dan konsentrasi hidrokoloid. Sedangkan pada HPMC, ditemukan bahwa ada interaksi awalantara protein hidrokoloid dan gluten yang mengurangi interaksi dengan molekul air. Pembentukan kompleks elektrostatik antara hidrokoloid anionik, seperti pektin, dan gluten dapat berperan dalam peningkatan kapasitas pengikatan air (Ribotta dkk., 2005). Semua hidrokoloid, dengan pengecualian gum arab, dapat menurunkan modulus viskoelastis selama pemanasan dan pendinginan, serta menghasilkan efek pelemahan pada gluten.

\section{KESIMPULAN}

Peranan hidrokoloid menjadi semakin penting untuk penyempurnaan pembuatan produk bakeri. Penambahan hidrokoloid pada adonan dapat meningkatkan stabilitas dan karakteristik kualitas lainnya seperti peningkatan penyerapan air, volume roti, dan sifat viskoelastis. Hidrokoloid juga berpengaruh terhadap sifat sensori dari produk akhir.

\section{DAFTAR PUSTAKA}

Albert S., Mittal G.S. 2002. Comparative evaluation of edible coatings to reduce fat uptake in a deep fried cereal product. Food Res. Inter. 35, 445-458.

Barcenas M.E., Rosell C.M. 2006. Different approaches for improving the quality and extending the shelf life of the partially baked bread: low temperatures and HPMC addition. J. Food Eng. 72, 92-99.
Barcenas, M.E., De la O-Kelle, J., Rosell, C.M., 2009. Influence of different hydrocolloids on major wheat dough components (gluten and starch).J. Food Eng, vol. 94, no. 3-4, pp. 241-247.

Gómez-Díaz D., Navaza J.M., 2003. Comments about rheological effects of food hydrocolloids addition. Food Agric. Environ. 1, 98-102.

Gurkin S., 2002. Hydrocolloids - Ingredients that add flexibility to tortilla processing. Cereal Foods World 47, 41-43.

Ji Q., Zhu K., Qian H., Zhou H., 2007. Staling of cake prepared from rice flour and sticky rice flour. Food Chem. 104, 53-58.

Kohajdova, Z., Karovicova, J. 2008. Influence of Hydrocolloids on Quality of Baked Goods. Acta Sci. Pol., Technol. Aliment., 7 (2): $43-49$

Le'on, A.E., Ribotta, P.D., Ausar, S.F., Fern'andez, C., Landa, C.A., and Beltramo, D.M., 2000. Interactions of different carrageenan isoforms and flour components in breadmaking. Journal of Agricultural and Food Chemistry, vol. 48, no. 7 , pp. 2634-2638.

Pahwa, A., Kaur, A., Puri, R., 2016. Influence of hydrocolloids on the quality of major flat bread: a review. Journal of Processing. Vol. 2016, Article ID 8750258.

Rao J., Prasad M.S., Rao G.V., 1992. Effect of xanthan on the rheological and bread making quality of wheat flour. J. Food Sci. Technol. India 29, 234-239.

Ribotta P.D., Le Bail A., 2007. Thermophysical assessment of bread during staling. LWT - Food Sci. Technol. 40, 879-884.

Ribotta, P.D., Ausar, S. F., Beltramo, d.m., and Le'on, A.E., 2005. Interactions of hydrocolloids and sonicated-gluten proteins. Food Hydrocolloids, vol. 19, no. 1, pp. 93-99. 
Rosell C.M., Rojas, J.A., Benedito C., 2001. Influence of hydrocolloids on dough rheology and bread quality. Food Hydrocol. 15, 75-81.

Schiraldi A., Piazza L., Brenna O., Vittadini E., 1996. Structure and properties of bread dough and crumb: calorimetric, rheological and mechanical investigations on the effects produced by hydrocolloids, pentosans and soluble proteins. J. Thermal Anal. 47, 13391360.

Schober T.J., Clarke CH.I., Kuhn M., 2002. Characterization of functional properties of gluten proteins in spelt cultivars using rheological and quality factor measurements. Cereal Chem. 79, 408417.

Shahzadi N., Butt M.S., Rehman S.U., Sharif K., 2005. Rheological and baking performance of composite flours. Inter. J. Agric. Biol. 7, 100-104.

Shalini K.G., Laxmi A., 2007. Influence of additives on rheological characteristics of wholewheat dough and quality of Chapatti (Indian unleavened flat bread) Part I-hydrocolloids. Food Hydrocol. 21, 110-117. 